\title{
COMMENTS
}

\section{"Reasonable Care" in Section 12(2) of the Securities Act of 1933}

The overall policy of the federal securities laws ${ }^{1}$ is to control abuses in the issuance and sale of securities by requiring disclosure of material information ${ }^{2}$ to purchasers. Until recently, private rights of action were freely implied under section $10(\mathrm{~b})$ of the Securities Exchange Act of $1934^{3}$ and rule $10 \mathrm{~b}-5,{ }^{4}$ promulgated by the

1 This comment is concerned primarily with the Securities Act of 1933; 15 U.S.C. $\S \S 77 \mathrm{a}-77 \mathrm{~mm}$ (1976) [hereinafter cited without cross-reference as 1933 Act], and the Securities Exchange Act of 1934, id. \$§ 78a-78kk [hereinafter cited without cross-reference as 1934 Act].

2 The definition of "material" accepted by the courts for the 1934 Act, see Affiliated Ute Citizens v. United States, 406 U.S. 128, 153-54 (1972), is substantially the same as that promulgated by the SEC under the 1933 Act in rule 405(l), 17 C.F.R. $\S 230.405(l)$ (1980):

The term "material", when used to qualify a requirement for the furnishing of information as to any subject, limits the information required to those matters as to which an average prudent investor ought reasonably to be informed before purchasing the security registered.

3 It shall be unlawful for any person, directly or indirectly, by the use of any means or instrumentality of interstate commerce or of the mails, or of any facility of any national securities exchange-

(b) to use or employ, in connection with the purchase or sale of any security registered on a national securities exchange or any security not so registered, any manipulative or deceptive device or contrivance in contravention of such rules and regulations as the Commission may prescribe as necessary or appropriate in the public interest or for the protection of investors.

1934 Act $\$ 10,15$ U.S.C. $\$ 78 j$ (1976).

- It shall be unlawful for any person, directly or indirectly, by the use of any means or instrumentality of interstate commerce, or of the mails or of any facility of any national securities exchange,

(a) To employ any device, scheme, or artifice to defraud,

(b) To make any untrue statement of material fact or to omit to state a material fact necessary in order to make the statements made, in the light of the circumstances under which they were made, not misleading, or

(c) To engage in any act, practice, or course of business which operates or would operate as a fraud or deceit upon any person, in connection with the purchase or sale of any security.

17 C.F.R. $§ 240.10 \mathrm{~b}-5$ (1980). 
Securities and Exchange Commission ("SEC") pursuant to its rulemaking power. Section $10(\mathrm{~b})$ and rule $10 \mathrm{~b}-5$ are phrased merely as prohibitions against fraudulent or misleading practices in the context of sales of securities, but the duty to refrain from such practices had been interpreted by the SEC and the courts as one running to purchasers, ${ }^{5}$ and therefore purchasers harmed by the willful or negligent ${ }^{6}$ violation of that duty could recover damages.

In 1976, however, in Ernst \& Ernst v. Hochfelder, ${ }^{7}$ the Supreme Court restricted the liberal implication of $10 \mathrm{~b}-5$ actions by reading into the statute a scienter requirement for private damage suits. The effect of the Court's decision is to remit plaintiffs who cannot show scienter to their explicit remedies for negligent misdisclosure under sections 11 and 12 of the Securities Act of $1933 .{ }^{8}$ These sections thus have acquired a new importance, and ambiguities in their language and articulation present problems of interpretation. Indeed, the difficulties are illustrated by the Sanders $v$. John Nuveen \& Co. litigation, which began as a $10 \mathrm{~b}-5$ suit in 1970 and finally has been resolved as a section 12(2) suit eleven years later. ${ }^{9}$

Unlike rule $10 \mathrm{~b}-5$, which is a blanket prohibition against the dissemination of misinformation by "any person . . . in connection with the purchase or sale of any security,",10 sections 11 and 12 of the 1933 Act impose specific duties on specific categories of persons. ${ }^{11}$ They also attempt to define the scope of the duties by outlining a degree of care that, if met, will be an affirmative defense to liability. What the sections leave unclear is whether the degrees of care demanded of the various classes of persons are the same. Accordingly, this comment first examines the legislative history and structure of these provisions of the 1933 Act, the case law explicating them, and certain external considerations relevant to their interpretation. Concluding that the standards of care in sections 11

s Ernst \& Ernst v. Hochfelder, 425 U.S. 185, 196-97 (1976); Blue Chip Stamps v. Manor Drug Stores, 421 U.S. 723, 730 (1975); Affiliated Ute Citizens v. United States, 406 U.S. 128, 150-54 (1972); Superintendent of Ins. v. Bankers Life \& Cas. Co., 404 U.S. 6, 13 n.9 (1971).

- Negligence was held to be a sufficient premise for liability in SEC v. Texas Gulf Sulphur Co., 401 F.2d 833, 854-55 (2d Cir. 1968), cert. denied, 394 U.S. 976 (1969).

7425 U.S. 185 (1976).

15 U.S.C. $\$ \S 77 \mathrm{k}-77 l$ (1976).

- See note 146 infra. See also text and notes at notes 144-153 infra.

1017 C.F.R. $\$ 240.10$ b-5 (1980); see note 4 supra.

11 See text and notes at notes 21-27 infra. 
and 12(2) were meant to differ, the comment then focuses on 12(2), the most problematic section. It examines how the buyer-seller relationship gives specific content to the duty of care demanded by section $12(2)$, looking first to analogous duties for general guidance, then to particular elements of the relationship that may affect the standard, and finally to the nature of the security involved.

\section{Background of the Problem}

Although a basic policy of both the Securities Act of 1933 and the Securities Exchange Act of 1934 is disclosure, the areas each act regulates and the methods by which disclosure is demanded differ. The 1933 Act addresses the issuance of securities and their initial sale, and its basic mechanism is the registration of the securities themselves. ${ }^{12}$ The 1934 Act concentrates on the sales process rather than on the securities. It provides for the registration of brokers, securities exchanges, and securities dealers' associations, and for the filing of information concerning listed issuers and their securities. ${ }^{13}$ It also sets certain industry standards directly; for ex-

121933 Act $\S 5,15$ U.S.C. $\S 77$ (1976). Certain classes of securities are exempted from registration in $i d$. $\S 3(\mathrm{a}), 15$ U.S.C. $\$ 77 \mathrm{c}(\mathrm{a})$ (1976), including: securities guaranteed by a governmental body or issued by a bank; commercial paper arising out of or used for current transactions and having a maturity of no more than nine months; securities issued by nonprofit organizations; securities issued by savings and loan and similar institutions; securities issued by firms regulated by the Interstate Commerce Commission; securities issued by receivers or trustees in bankruptcy; insurance or endowment policies and annuity contracts regulated by another governmental body; securities exchanged by the issuer for those held by its existing security holders; securities issued in exchange for other property interests after the fairness of the exchange has been determined at a hearing by a federal court or agency; and securities offered and sold only to residents of the same state or territory in which the issuer is incorporated or does business. Registration also is not required for securities the SEC exempts by its rules and regulations, as long as the amount of the issue publicly offered does not exceed $\$ 500,000$, id. § $3(\mathrm{~b})$, and securities issued by small investment companies, if the SEC chooses to exempt them, id. § 3(c).

Certain transactions are exempted from the registration requirement by id. $\$ 4,15$ U.S.C. $\S 77 d$ (1976): transactions by those other than securities market professionals; transactions by issuers that do not involve a public offering; transactions by dealers that are not close to or part of the initial offering; transactions by brokers to fill unsolicited customers' orders; and transactions involving the sale of promissory notes secured by real estate, as long as the notes are originated by government-regulated institutions and the sale meets certain other requirements.

13 See 1934 Act $\S 12$, 15 U.S.C. $\$ 78 l$ (1976) (registration of securities sold on securities exchanges); id. $\S 13$, 15 U.S.C. $\$ 78 \mathrm{~m}$ (1976) (periodic reports by issuers to keep information on themselves and their securities current); id. $\$ 15,15$ U.S.C. $\S 780$ (1976) (registration of brokers and dealers); id. \$ 6, 15 U.S.C. $\$ 78 \mathrm{f}$ (1976) (registration of securities exchanges); id. $\S 15 \mathrm{~A}, 15$ U.S.C. $\S 780-3$ (1976) (registration of dealers' associations); id. § 16, 15 U.S.C. $\S 78 p$ (1976) (registration of directors, officers, and principal stockholders of issuers). 
ample, it mandates margin requirements for brokers. ${ }^{14}$ Both acts prohibit the parties they govern from making material misstatements or misleading omissions related to the sale of securities. The 1934 Act does so in section $10(\mathrm{~b})$ and rule $10 \mathrm{~b}-5$, under which private rights of action by purchasers have been implied. The language of section 17(a) of the 1933 Act $^{15}$ contains a similar ban, but implication of private rights of action under that section has been restrained by the presence of explicit remedial provisions in sections 11 and 12 of the same act and by the availability of $10 \mathrm{~b}-5$ actions. ${ }^{16}$ The recurrence of these "antifraud" provisions emphasizes that the acts share a common goal, despite the differences in their vantage points.

A more detailed consideration of the 1933 Act further illustrates how the two statutory schemes converge. The basic requirement of the 1933 Act is that certain parties closely involved in the issuance of the securities (the issuer and its officers) prepare a registration statement. ${ }^{17}$ The registration statement contains information about the issuer, such as its name, type and place of business, directors, principal owners, and financial condition; about the se-

14 See id. § 7, 15 U.S.C. § 78g (1976) (margin requirements); id. § 8, 15 U.S.C. $\S 78 \mathrm{~h}$ (1976) (restrictions on borrowing).

1515 U.S.C. $\$ 77 q(a)(1976)$ :

It shall be unlawful for any person in the offer or sale of any securities by the use of any means or instruments of transportation or communication in interstate commerce or by the use of the mails, directly or indirectly-

(1) to employ any device, scheme, or artifice to defraud, or

(2) to obtain money or property by means of any untrue statement of a material fact or any omission to state a material fact necessary in order to make the statements made, in light of the circumstances under which they were made, not misleading, or

(3) to engage in any transaction, practice, or course of business which operates or would operate as a fraud or deceit upon the purchaser.

Section 17(a) was the model for rule 10b-5. See Conference on Codification of the Federal Securities Laws, 22 Bus. LAw. 793, 922 (1967).

16 There are some differences between an action implied from section 17(a) and one implied from rule $10 \mathrm{~b}-5$, and these differences have been urged alternately as reasons to prohibit and reasons to allow section 17(a) actions. Compare Horton, Section 17(a) of the 1933 Securities Act-The Wrong Place for a Private Right, 68 Nw. U.L. Rev. 44 (1973) with Note, Implied Civil Remedies Under Section 17(a) of the Securities Act of 1933, 53 B.U.L. Rev. 70 (1973). This debate is irrelevant to the point here, however: such actions have not been an important phenomenon, and now that rule 10b-5 actions have been limited so as not to compete with sections 11 and 12(2), it is unlikely that courts will allow section 17 (a) actions to blossom and fill that void, a course recommended by Note, Section 17(a) of the 1933 Securities Act: An Alternative to the Recently Restricted Rule 10b-5, 9 RUT.-CAM. L.J. 340 (1978).

191933 Act § 6, 15 U.S.C. § 77f (1976). 
curities proposed to be issued, such as their purpose and amount, anticipated proceeds from their sale, and offering price; about the underwriter of the proposed issue, such as its name, its sales commission, and a copy of the underwriting agreement; and other details. ${ }^{18}$ The statement is filed with the SEC, which reviews it and may demand revisions, although the Commission does not guarantee the statement's accuracy to the public. ${ }^{19}$ The registration statement itself is thereafter publicly available on request. In addition, every seller must furnish the purchaser with a prospectus containing the registration statement's most basic information. ${ }^{20}$

Two sections define the liability of parties governed by the Act for failure to comply with its disclosure requirements. Section $11^{21}$ covers those responsible for producing the registration statement. It makes the signatories of the statement, present and incipient directors of the issuer, auditors or other experts who have prepared parts of the statement or reports on which the statement is based, and underwriters, liable to purchasers of the security if the registration statement "contained an untrue statement of a material fact or omitted to state a material fact required to be stated therein or necessary to make the statements therein not misleading." ${ }^{22}$ Each of these parties may avoid liability, however; if he can prove he used sufficient care to comply with the disclosure require-

${ }^{18}$ Id. $\S 7,15$ U.S.C. $\S 77 \mathrm{~g}$ (1976); Schedules A \& B, 15 U.S.C. § 77aa (1976). The registration statement forms prescribed by the SEC, 1 DonNELLEY SEC HANDBOoK 3-2-3 to -10-1 (1980), give specific guidance for meeting the statute's demands. The precise requirements vary with the type of security.

${ }^{19}$ Congress recognized that SEC verification of this information would be impracticable, and opted instead for a mechanism that required disclosure and expanded liability for misdisclosure to encourage private enforcement. Congressional hearings indicate that the intent of the statute was merely to give purchasers the same informational advantages as issuers, and to allow them to invest in speculative securities with open eyes. Congress did not mean to make either the government, which was to manage the informational network, or the issuer guarantors of the securities. See Federal Securities Act: Hearings on H.R. 4314 Before the House Comm. on Interstate and Foreign Commerce, 73d Cong., 1st Sess. 57-58, 141 (1933) [hereinafter cited as 1933 House Hearings]. The brief letter from President Roosevelt to Congress calling for the legislation was careful to caution against a scheme of government approval of securities. Letter from Franklin D. Roosevelt to Congress (Mar. 29, 1933) [hereinafter cited as Roosevelt Letter], reprinted in 1933 House Hearings, supra, at 1. That caution continues in the present law: the prospectus furnished to purchasers of securities must state prominently in large type that the SEC has neither verified the information it contains nor approved the securities. Rule 425, 17 C.F.R. $\$ 230.425$ (1980).

${ }^{20} 1933$ Act $\S 5(b)(2)$, 15 U.S.C. $\S 77 \mathrm{e}(\mathrm{b})(2)$ (1976); id. § 10, 15 U.S.C. $\S .77 j$ (1976). The prospectus is simply part 1 of the registration statement. See Form S-1, pt. 1, 1 DonnelleY SEC HANDBOoK, supra note 18 , at 3-2-3 to -20 .

${ }^{21} 15$ U.S.C. § 77k (1976).

${ }^{22}$ Id. $\$ 77 \mathrm{k}(\mathrm{a})$. 
ments. ${ }^{23}$ The section specifies in detail what constitutes sufficient care: he must have had, "after reasonable investigation, reasonable ground to believe" that there was no misstatement or omission. ${ }^{24}$ He may rely on statements of experts and "official persons" as long as "he had no reasonable ground to believe and did not believe" that they were false or incomplete. ${ }^{25}$ The standard of reasonableness is "that required of a prudent man in the management of his own property."26

Section $12,{ }^{27}$ which applies to sellers of securities, both reinforces section 11 and creates independent liabilities. Section 12(1) imposes strict liability on those who sell securities that should have been registered but were not. Insofar as sellers are deterred by 12(1), it also operates to cut off the means of distribution for issuers who flout section 11's registration requirements. Section 12(2)'s relationship to section 11 is more complex. Like section 11 , it imposes liability for misdisclosure, here on sellers whose prospectuses or other written or oral statements in connection with a sale are misleading. Like section 11, it provides an affirmative defense; but it describes the defense merely as "reasonable care," and unlike section 11, it does not further define the phrase. In its application to prospectuses, which are part of the registration statement, section 12(2) encourages sellers to police issuers and insiders-a form of secondary enforcement of section 11. In its application to the seller's own representations, section 12(2) is a primary enforcement mechanism on sellers themselves. Furthermore, in both its primary and secondary aspects, section $12(2)$ reaches all sellers, a category that comprehends both underwriters (also covered by section 11) and brokers and dealers (covered by section 12 alone).

Thus a purchaser complaining of fraudulent or deceptive practices in the context of a sale of securities could, at least before the

2s The issuer itself is strictly liable for such misstatements or omissions. $I d . \S 77 \mathrm{k}(\mathrm{b})$.

24 Id. $\$ 77 \mathrm{k}(\mathrm{b})(3)(\mathrm{A})-(\mathrm{B})$.

${ }^{28}$ Id. $\S 77 \mathrm{k}(\mathrm{b})(3)(\mathrm{C})-(\mathrm{D})$.

${ }^{26} I d$. $\$ 77 \mathrm{k}(\mathrm{c})$. As originally enacted, this section provided that the standard of care was "that required of a person occupying a fiduciary relationship." Securities Act of 1933, ch. $38, \S 11(\mathrm{c}), 48$ Stat. 83. Congress modified this strong language to its present form in 1934, Securities Exchange Act of 1934, ch. 404, $\$ 206$ (c), 48 Stat. 907, in response to anxiety in the investment community, but intended to effect no change in its force. H.R. REP. No. 1838, 73d Cong., 2d Sess. 41 (1934); 78 Cong. REc. 8669 (1934) (memorandum of Sen. Fletcher). The new language merely substituted the standard definition of a trustee's duty of care as contained in the contemporary Restatement of Trusts $\S 169$ (Tent. Draft No. 2, 1931), for the term "fiduciary."

2715 U.S.C. § $77 l$ (1976). 
limiting of $10 \mathrm{~b}-5$ actions, state his claim under the sales-oriented 1934 Act. Or he could sue under section 11 or section 12 of the 1933 Act, depending on the status of the misleading party. ${ }^{28}$ Section $12(2)$ is the most obviously Janus-like: it premises liability both on misdisclosure in the prospectus, a document at the heart of the 1933 Act's scheme, and on misdisclosure in other sales representations, activities on which the 1934 Act is more sharply focused. The principal distinctions between these apparently interchangeable remedies are that the time and remedy limitations under the 1933 Act are more stringent. ${ }^{29}$ In Ernst \& Ernst $v$. Hochfelder, however, the Supreme Court thought that the remedial provisions of the two acts should be treated as organic rather than competitive. ${ }^{30}$ It therefore decided to remit purchasers of securities who were harmed by negligent misrepresentations to the more specific remedies of sections 11 and 12 of the 1933 Act. $^{31}$

By diverting large numbers of purchaser suits into the 1933 Act's ambit, the Court has focused attention on the affirmative de-

28 Although the 1933 Act is not primarily concerned with regulating sales, the behavior it prohibits can become civilly actionable only in the sales context.

${ }^{20}$ Remedies under section 10 (b) of the 1934 Act could be more liberal primarily because this statute, which does not explicitly authorize private actions for damages at all, also does not restrict what damages are recoverable. Sections 11 and 12 of the 1933 Act-limit their explicit remedies to rescission if the purchaser still owns the security at the time of suit, or the amount the purchaser paid less the amount gained on resale (the counterpart of rescission as a making-whole remedy) if he has disposed of it, plus awards of attorney's fees.

Sections 11 and 12 of the 1933 Act also have strict statutes of limitations. See 1933 Act $\S 13,15$ U.S.C. $\S 77 \mathrm{~m}$ (1976). Actions under section 11 (by purchasers against those closely associated with the issuance of the security, for false or misleading information in the registration statement required by the 1933 Act) must be brought within one year of the time when the misinformation should, with reasonable diligence, have been discovered, but no more than three years after the security was publicly offered. Actions under section 12(1) (by purchasers against sellers for selling unregistered securities that should have been registered) must be brought within one year of the sale, but no more than three years after the public offering. Actions under section 12(2) (by purchasers against sellers for false or misleading oral or written sales information) must be brought within one year of reasonable discovery of the misinformation, but no more than three years after the sale. By contrast, there is controversy over what statute of limitations should apply to rule $10 \mathrm{~b}-5$ actions. See, e.g., Bateman \& Keith, Statutes of Limitations Applicable to Private Actions Under SEC Rule 10b-5: Complexity in Need of Reform, 39 Mo. L. REv. 165 (1974); Martin, Statutes of Limitation in 10b-5 Actions: Which State Statute is Applicable?, 29 Bus. Law. 443 (1974).

so 425 U.S. at 206-11.

${ }^{31}$ Cf. Lanza v. Drexel \& Co., 479 F.2d 1277, 1309 (2d Cir. 1973) (en banc):

To argue that a section of the 1934 Act, which neither by its terms nor its history manifests a similar attention to the careful balance struck in Section $11, \ldots$ impose[s] upon directors the same duties as Section 11 and more, is to thwart, not serve, the purpose of Congress and the dictates of sound policy . . . . 
fenses in sections 11 and 12. As noted earlier, ${ }^{32}$ section 12(1) affords no defenses. Section 11's "reasonable investigation" requirement is extensively glossed. Section 12(2)'s "reasonable care" requirement is relatively unexplicated. Thus the relationship between "reasonable investigation" and "reasonable care," and the specific content of the diligence requirement of section 12(2), require definition.

\section{Sections 11 and 12(2): The Relative Standard of Care}

\section{A. Legislative History}

Congress passed the Securities Act of 1933 in an atmosphere of indignation and anxiety over the losses suffered in the market collapse; the goal was to restore confidence in investment and to reverse the psychology of depression. ${ }^{33}$ Its perception of the problem illuminates the structure of section 11 of the Act. A leitmotif in the hearings on the originally proposed bill, and in the bill itself, is the conviction that issuers and their agents must assume greater accountability to purchasers of the securities they distribute. The responsibility of directors was a particular object of concern because of the indiscriminate use of armies of "dummy" directors-eminent men who served as figureheads for advertising purposes and collected fees for their endorsements ${ }^{34}$ but did not

s2 See text and note at note 27 supra.

ss See 1933 House Hearings, supra note 19, at 207 (remarks of Rep. Sabath):

We must act. We must have legislation, not only to protect the people in the future, but to bring about the punishment of the men who brought about ruin to $20,000,000$ American people, who are responsible for thousands upon thousands of suicides; who brought about a condition that has destroyed the value of the property of the men, women, and children of America; a condition that has brought about destruction of the property of widows and orphans; and that has closed the banks, ruined business men and manufacturers in every section of the Nation.

... We must reestablish confidence. . . . Not until confidence is reestablished can we expect that conditions of this country will improve again.

This comment does not seek to add to the extensive literature challenging the effectiveness of the scheme adopted in the 1933 Act in attaining these goals. Rather, it seeks only to explicate the statute as it was enacted.

s4 [I]n London financial circles they call those directors who go around attending meetings "guinea pigs", because every man gets a guinea for every meeting he attends. In New York they have not named them, but there are many men in New York on many boards of directors whose sole business is to attend meeting after meeting of directors, for which they receive $\$ 10$ or $\$ 20$. They hold themselves out to the public, or their names are held out to the public, in order to sell the public.

1933 House Hearings, supra note 19, at 125 (remarks of Rep. Marland). 
actually direct. ${ }^{35}$ The solution proposed by the original bill and debated in the congressional hearings was to impose on all directors a very high degree of responsibility: strict liability to purchasers in cases of misrepresentation, no matter how innocent. ${ }^{36}$

The proposal was expected to have two desirable effects. First, it would excise idle supernumeraries from many boards, leaving only those who were committed and competent to continue as directors. ${ }^{37}$ Second, it would provide relief to purchasers harmed by misrepresentations. Holding directors strictly liable, even if they could not have prevented the harm and were not morally culpable, was justified on the following basis: in choosing which of two nonculpable parties should bear the costs of a mistake, it was fairer to make the director pay, because he had made the mistake and he stood to profit from directing the company and selling its securities. ${ }^{38}$ The force and frequency with which this argument was advanced demonstrate the willingness of some legislators to impose a greater burden than the common law fraud rules would have imposed.

Several considerations suggested lightening the burden somewhat, however. First, even the most diligent director could not verify every fact required in the registration statement; he had to rely at least in part on information compiled by others. ${ }^{39}$ The English

35 I know that there are men sitting on boards of directors of banks and other corporations who never attend meetings, and their names are used, and they permit their names to be used in fact, for publicity purposes. That sort of thing is reprehensible, and there should be some way of reaching them.

Securities Act: Hearings on S. 875 Before the Senate Comm. on Banking and Currency, 73d Cong., 1st Sess. 205 (1933) (remarks of Sen. Couzens) [hereinafter cited as 1933 Senate Hearings]. See also 1933 House Hearings, supra note 19, at 122 (remarks of Rep. Parker); id. at 123 (remarks of Rep. Merritt); id. at 125 (remarks of Rep. Marland); 1933 Senate Hearings, supra, at 271 (statement of Ollie M. Butler).

${ }^{36}$ See H.R. 4314, 73d Cong., 1st Sess. § 9, reprinted in 1933 House Hearings, supra note 19, at 6; S. 875, 73d Cong., 1st Sess. $\$ 9$, reprinted in 1933 Senate Hearings, supra note 35 , at 6.

37 1933 House Hearings, supra note 19, at 215 (statement of Houston Thompson). See also id. at 216 ("I would be surprised if you could find any man so dumb in the face of this law, who would become a dummy director, with the penalties of this act staring him in the face"); 1933 Senate Hearings, supra note 35, at 208 (statement of Alexander Holtzoff); id. at 271 (statement of Ollie M. Butler).

${ }^{38} 1933$ Senate Hearings, supra note 35, at 271 (statement of Ollie M. Butler). This notion was reiterated throughout the hearings, often in nearly identical language. See 1933 House Hearings, supra note 19, at 122 (statement of Ollie M. Butler); id. at 124-25 (statement of Houston Thompson; remarks of Rep. Mapes); id. at 244-45 (statement of Robert E. Healy); 1933 Senate Hearings, supra note 35, at 204-05, 206, 207 (statement of Alexander Holtzoff); id. at 249 (statement of Ollie M. Butler).

so The argument that directors must rely on experts recurs throughout the hearings. 
Companies Act, one of the models examined by the framers of the 1933 Act, provided that directors could rely on information certified by auditors and thereby avoid otherwise strict liability. ${ }^{40}$ It prompted the suggestion that the same procedure be adopted in the American law. ${ }^{12} \mathrm{Had}$ the British system of government regulation of auditors also been adopted in the United States, this proposal would have been more appealing; but allowing reliance on experts without such an independent restraint on the experts themselves was repeatedly rejected in the congressional hearings. ${ }^{42}$

Second, there was apprehension that strict liability would inhibit even beneficial activity, contrary to President Roosevelt's call for "legislation ... to protect the public with the least possible interference to honest business." 4 segitimate and conscientious directors might be impeded by sanctions originally designed to get rid of directorial deadwood. ${ }^{44}$ There was even a fear expressed

See, e.g., 1933 Senate Hearings, supra note 35, at 248 (remarks of Sen. Couzens): "[T] he serious director . . . wants to be guided, and obviously has to be guided, by somebody that knows more about these things than he does." See also id. at 206-10 (remarks of Sen. Couzens); id. at 208 (remarks of Sen. Adams).

10 Companies Act, 1929, $19 \& 20$ Geo. 5, c. 23, 37 (reenacted in Companies Act, 1948; $11 \& 12$ Geo. 6 , c. $38, \S 43)$.

11 Discussion of this suggestion occurs throughout the hearings. See 1933 House Hearings, supra note 19, at 121 (statement of Ollie M. Butler, remarks of Rep. Parker); id. at 124 (statement of Ollie M. Butler); id. at 168-71 (statement of William C. Breed); id. at 191 (suggested amendments presented by William C. Breed); id. at 216 (statement of Houston Thompson, remarks of Reps. Rayburn, Parker, and Kenney); 1933 Senate Hearings, supra note 35, at 204-10 (remarks of Sens. Gore, Couzens, and Adams); id. at 247-48 (statement of Ollie M. Butler, remarks of Sen. Couzens).

12 See, e.g., 1933 House Hearings, supra note 19, at 216 (statement of Houston Thompson):

[T] he British accountant is in a totally different situation from the accountant in

America. He not only belongs to an organization, but he is a chartered accountant, and responsible to the Government. $\mathrm{He}$ is responsible for fraud. He is responsible for gross carelessness. He is responsible in many ways, so that the accountant is just as anxious to have the truth known as the director would be to have the truth known and that is the reason why the British act deals with him as it does.

Under American law, if the director could shift responsibility to the unregulated accountant, "you would not have anybody who would be financially responsible for a misstatement." 1933 Senate Hearings, supra note 35, at 208 (statement of Alexander Holtzoff). If liability remained on the director, then the purchaser would not suffer for the director's mistakes, and the director would have an incentive to choose competent auditors. See 1933 House Hearings, supra note 19, at 122 (statement of Ollie M. Butler). See also id. at 123, 124; 1933 Senate Hearings, supra note 35, at 206-10 (statement of Houston Thompson); id. at 248, 270-71 (statements of Ollie M. Butler).

is Roosevelt Letter, supra note 19.

11 One witness at the Senate hearings asked:

Where is there a director of any corporation just about to issue securities that would dare to sit on a board in this country if this act, as now drawn, goes through? $\mathrm{He}$ 
that holding directors strictly liable would amount to an unconstitutional prohibition-rather than a regulation-of interstate commerce. 45

Thus there were two particular areas of tension in the debates about the precursor of section 11 . One was an issue of scope: could directors rely on experts or were they required to take responsibility for all statements, however indirect their own knowledge might be? The other issue involved the standard of care: apart from the protection vel non of reliance on experts, was strict liability an undesirably high standard?

The bills subsequently reported out of the Senate and House committees reflect these tensions. The Senate proposal ${ }^{16}$ retained strict liability in all cases, and did not allow reliance on experts. ${ }^{47}$

cannot rely upon anything; he must know it all, in a small company or a large company. He must sign the statement with a detailed list of assets and liabilities and properties, accounts receivable and accounts payable. Could you or I sit on a board of directors and take personal and individual liability if there is a mistake in any one of those figures...?

1933 Senate Hearings, supra note 35, at 126 (statement of William C. Breed). See also id. at 92-93 (letter of H.C. Hopson); id. at 205, 207 (remarks of Sen. Gore); id. at 209-10 (remarks of Sen. Couzens).

45 1933 House Hearings, supra note 19, at 39 (statement of Houston Thompson, remarks of Rep. Lea); 1933 Senate Hearings, supra note 35, at 126-27, 175-77 (statements of William C. Breed).

46. S. 875, 73d Cong., 1st Sess. § 9 (1933). choices:

17 The Senate Committee on Banking and Currency explained its reasons for these

The question is whether ignorance of an untruth should excuse the director and leave the loss upon the buyer. To do so in our opinion would fail to give the buyer the needed relief and fail to restore confidence. If one of two presumably innocent persons must bear a loss, it is familiar legal principle that he should bear it who has the opportunity to learn the truth and has allowed untruths to be published and relied upon. ...

$\cdots$

Accordingly the registration of false information under the bill makes not only the issuer, but the directors who sign, civilly liable for return of the money which the purchaser paid for the security. If a director can excuse himself by saying that he has in good faith relied upon an accountant's statement, or the statement of some other person, then the investor will continue in the same position from which the Nation is struggling to extricate him. . . .

This phase of the law will have a direct tendency to preclude persons from acting as nominal directors while shirking their duty to know and guide the affairs of the corporation. ...

The committee believes that making directors and officers personally liable will result in persons retiring from many boards and confining their efforts to a few boards where they will actually direct.

S. Rep. No. 47, 73d Cong., 1st Sess. 5 (1933). 
The House bill, ${ }^{48}$ however, reduced the general standard of care demanded and broadened the class of people subject to the standard. Although the issuer itself remained strictly liable for misstatements and omissions, for all others with inside responsibility the bill replaced strict liability with a fiduciary's standard of care and allowed reasonable reliance on experts. However, as a trade-off for allowing reliance, the bill subjected experts themselves to liability for misrepresentations in their statements, if they failed to meet the same standard of care. ${ }^{40}$ Despite these moderations, the House committee thought the bill would be effective in achieving the same preventive and remedial objectives sought by the Senate, because the burdens it imposed remained very high. ${ }^{50}$

The common ground between the Senate, with its strict liability language, and the House, with its somewhat lower but more comprehensive standard of care, seems to be an intent to impose a burden as close to strict liability as was thinkable. ${ }^{51}$ In light of the

13 H.R. 5480, 73d Cong., 1st Sess. (1933).

19 See H.R. Conr. REP. No. 152, 73d Cong., 1st Sess. 26 (1933), accompanying the bill as finally enacted, which followed the House bill's framework:

Delegation to others of the performance of acts which it is unreasonable to require that the fiduciary shall personally perform is permissible. Especially is this true where the character of the acts involves professional skill or facilities not possessed by the fiduciary himself. In such cases reliance by the fiduciary, if his reliance is reasonable in the light of all the circumstances, is a full discharge of his responsibilities. In choosing between these two standards of liability, the Senate accepted the standards imposed by the House bill.

Though the standards of the Senate amendment were more severe than those embodied in the House bill, the classes of persons upon whom liability was imposed were less. The House bill imposed liability upon the underwriters and also upon the experts, such as accountants, appraisers, and engineers, who gave the authority of their names to statements made in the registration statement.

See also J. Wirsen, The Securities Acts and Independent Auditors: What Did Congress INTEND? 34-36 (1978).

so H.R. REP. No. 85, 73d Cong., 1st Sess. 5 (1933):

Honesty, care, and competence are the demands of trusteeship. These demands are made by the bill on the directors of the issues [sic], its experts, and the underwriters who sponsor the issue. If it be said that the imposition of such responsibilities upon these persons will be to alter corporate organization and corporate practice in this country, such a result is only what your committee expects. . . . But to require [directors] to guarantee the absolute accuracy of every statement that they are called upon to make, would be to gain nothing in the way of an effective remedy and to fall afoul of the President's injunction that the protection of the public should be achieved with the least possible interference to honest business.

s2 See id. at 10: "To impose a lesser responsibility would nullify the purposes of this legislation. To impose a greater responsibility, apart from constitutional doubts, would unnecessarily restrain the conscientious administration of honest business with no compensating advantage to the public."

There has been some academic debate about the statute's actual effect on common law 
clear indications in the legislative history that it only reluctantly reduced that standard from strict liability to liability for slight negligence, Congress might have executed its demand for abundant care by calling in the statute for "reasonable care under the circumstances." The compromise provision finally enacted as section 11 , however, is much more specific. It defines an exacting standard of reasonableness, ${ }^{52}$ makes investigation a prerequisite for avoiding liability, ${ }^{53}$ and subjects experts. themselves to potential liability. ${ }^{54}$

It is noteworthy that the early debate focused entirely on directors and experts. The bills as originally introduced did not cover underwriters as a category, ${ }^{55}$ and vendors of securities were liable only for deliberate misrepresentations. In revising the bill the House committee broadened its coverage to make underwriters liable for negligent misrepresentation, ${ }^{58}$ but the Senate committee retained the original bill's scheme. The conference committee

duties. Folk, Civil Liabilities Under the Federal Securities Acts: The BarChris Case (pt. 1), 55 VA. L. REv. 1, 42-45 (1969), argues that the duty of a director was already a fiduciary duty at common law. He doubts that the draftsmen of the 1933 Act intended to establish a still higher standard, the standard to which the trustee of an express trust is held. Instead he explains the strong language of the debates and the enacted legislation as an expression of outrage that the common law standard had not been properly enforced. One of the witnesses at the congressional hearings had also expressed a belief that the proposed legislation was merely declaratory of existing law; but his belief must have been mistaken, because the provision to which he referred was the strict liability proposal that evolved into section 11 . 1933 House Hearings, supra note 19, at 125 (statement of Ollie M. Butler).

Against Folk's interpretation, there is Congress's own statement that "[t]he responsibility imposed is no more nor less than that of a trust." H.R. REP. No. 85, 73d Cong., Ist Sess. 9 (1933). A contemporary commentator also thought that Congress was departing from the common law by raising the standard of care to a fiduciary standard. Shulman, Civil Liabilities and the Securities Act, 43 YALE L.J. 227, 248 (1933).

Whatever the strict truth is about a director's duties at common law, it seems indisputable that Congress thought it was defining duties stricter than those to which directors had hitherto been subject. This perception is important in determining the relative weight of the burdens Congress intended to impose on nondirectors.

${ }^{32} 15$ U.S.C. $\& 77 \mathrm{k}(\mathrm{c})(1976)$.

${ }^{83} I d . \S 77 \mathrm{k}(\mathrm{b})$. Someone is required to investigate every portion of the official representations, either the expert, on whose "expertised" portions the nonexperts may rely, or the nonexpert, who must verify the non-"expertised" portions.

st Id.

ss "Underwriter" is defined in 1933 Act $\S 2(11), 15$ U.S.C. $\$ 77 \mathrm{~b}(11)$ (1976), as any person who has purchased from an issuer with a view to, or offers or sells for an issuer in connection with, the distribution of any security, or participates or has a direct or indirect participation in any such undertaking, or participates or has a participation in the direct or indirect underwriting of any such undertaking; but such term shall not include a person whose interest is limited to a commission from an underwriter or dealer not in excess of the usual and customary distributors' or sellers' commission.

se H.R. REP. No. 85, 73d Cong., 1st Sess. 5 (1933). 
adopted the House version. ${ }^{57}$ Apparently, Congress thought underwriters were closely enough involved in and responsible for the issuance and promotion of securities to warrant classifying them as insiders and subjecting them to the same standard of care expected of directors. ${ }^{58}$

More interestingly, it was not until the compromise between the Senate and House versions that the class of sellers qua sellers (a class that includes, but is larger than, underwriters) was given independent responsibility for negligent misrepresentation under section 12(2). The motivations for enacting section 12(2) of the 1933 Act are as murky ${ }^{58}$ as the motives for enacting section 11 are clear. The bill originally proposed made vendors liable for knowing falsity ${ }^{60}$ a provision that altered the common law of fraud only in relieving purchasers of the need to show reliance on the vendors' statements. $^{61}$ It also made the liability of signatories of the regis-

${ }^{87}$ H.R. CoNf. ReP. No. 152, 73d Cong., 1st Sess. 26 (1933), quoted in note 49 supra.

ss The centrality of the underwriter's role in the issuance and promotion of new securities is often cited as a justification for this burden. See, e.g., Chris-Craft Indus., Inc. v. Piper Aircraft Corp., 480 F.2d 341, 370 (2d Cir.), cert. denied, 414 U.S. 910 (1973):

No greater reliance in our self-regulatory system is placed on any single participant in the issuance of securities than upon the underwriter. He is most heavily relied upon to verify published materials because of his expertise in appraising the securities issue and issuer, and because of his incentive to do so. He is familiar with the process of investigating the business conditions of a company and possesses extensive resources for doing so. Since he often has a financial stake in the issue, he has a special motive thoroughly to investigate the issuer's strengths and weaknesses. Prospective investors look to the underwriter-a fact well known to all concerned and especially to the underwriter-to pass on the soundness of the security and the correctness of the registration statement and prospectus.

so The President's message to Congress recommending the enactment of securities legislation boasted that " $[t]$ his proposal adds to the ancient rule of caveat emptor, the further doctrine 'let the seller also beware." "Roosevelt Letter, supra note 19. It is clear from the context of this and other references to sellers in the congressional hearings that the term was being used loosely, as the opposite of "buyer," to refer to the main objects of concern: the issuer and directors who originated the securities. In the act as adopted, however, the term "seller" has acquired a more technical meaning; otherwise section 12 would make no sense in juxtaposition to section 11. Although the Act defines "sale" and "sell" in section 2(3), 15 U.S.C. \& 77b(3) (1976), it does not define "seller."

${ }^{\circ}$ H.R. 4314, 73d Cong., 1st Sess. $\$ 9$ (1933), reprinted in 1933 House Hearings, supra note 19, at 6; S. 875, 73d Cong., Ist Sess. $\$ 9$ (1933), reprinted in 1933 Senate Hearings, supra note 35 , at 6 :

In case any such statement shall be false in any material respect, any persons acquiring any securities to which such statement relates, either from the original issuer or from any other person, shall have the right to rescind the transaction and to obtain the return, either at law or in equity, of any and all consideration given or paid for any such securities upon the surrender thereof, either from any vendor knowing of such falsity or from the persons signing such statement, jointly or severally . . . .

-1 The elements of the common law action of deceit are: a false representation by the 
tration statement-that is, directors-run with the security, so that every purchaser of the security, no matter who his vendor was, could claim his remedy from the source. ${ }^{62}$ Far from wanting to put increased burdens on sellers, the framers of the original bill were reluctant even to require sellers (other than underwriters) to deliver a copy of the prospectus as a routine part of each sale. ${ }^{63}$

Section 12(2) as enacted, however, makes it a defense that the seller "did not know, and in the exercise of reasonable care could not have known, of [the actionable] untruth or omission." "64 Here, as in section 11, the initial provision was altered significantly in the legislative process. However, the direction of the compromise in section 12(2) was toward increasing the scope of the liability-to cover negligent as well as knowing misrepresentations. In section 11 , the movement had been in the opposite direction-from strict liability to a liability that admitted of some defenses. There is no reason to assume that the two migrations met at a midpoint and created a single standard of liability for section 11 and section 12(2) defendants. There is thus no basis for construing "reasonable care" in section 12(2) as picking up all the investigative duties imposed by section 11 .

Congress seems rather to have operated on an understanding that the various links in the chain of distribution have characteristic responsibilities ${ }^{65}$ and that sections 11 and $12(2)$, taken together, cover that chain and apply to each link a set of appropriate requirements:

All who sell securities with such a flaw [material misrepresentation or omission], who cannot prove that they did not know-or who in the exercise of due care could not have known-of such misstatement or omission, are liable under sections 11 and 12. For those whose moral responsibility to the public is particularly heavy, there is a correspondingly heavier legal liability-the persons signing the registration statement, the underwriters, the directors of the issuer, the

defendant, scienter, intent to influence the plaintiff's action, justifable reliance by the plaintiff, and damage. W. Prosser, Handbook of the LAW OF TORTS 685-86 (4th ed. 1971).

${ }^{62}$ See note 60 supra.

os 1933 House Hearings, supra note 19, at 36-37 (statement of Houston Thompson).

4 15 U.S.C. $\$ 77 l$ (1976).

os "The duty of care to discover varies in its demands upon participants in security distribution with the importance of their place in the scheme of distribution and with the degree of protection that the public has a right to expect." H.R. REP. No. 85, 73d Cong., 1st Sess. 9 (1933). 
accountants, engineers, appraisers, and other professionals preparing and giving authority to the prospectus-all these are liable to the buyer not only if they cannot prove they did not know of the flaw in the information offered the public but also if they cannot prove they could not have found that flaw "after reasonable investigation" and that they "had reasonable ground to believe and did believe $* * *$ that such statement was true or that there was no such omission."

The difficulty is that the statutory scheme is reminiscent both of wheels within wheels and of categories along a spectrum. The wheel-within-a-wheel metaphor is suggested by the congressional language just quoted: section 12(2), despite its shrouded origins, seems to be the general provision, and section 11 the particularizing one. Given its theory of a chain of distribution, with duties corresponding to each link, Congress could have drafted a single provision that called for "reasonable care under all of the circumstances." Instead it saw a need to specify and created two provisions: section $12(2)$, requiring reasonable care in the ordinary sense, and section 11 , requiring a more explicitly defined version of reasonable care, in which the reasonableness expected is that of a fiduciary and the care always requires an investigation. At the same time, the legislative history of the enactment of sections 11 and 12(2) suggests that directors, experts, and underwriters were thought to be at one end of a spectrum, and vendors at the other. The most likely explanation of this confusion of metaphors is that the section 11 standard of care is both presumptively higher, because section 11 preselects the cases in which the general standard would be most demanding, and more particularized, as a result of the special status of section 11 defendants.

\section{B. Subsequent Analysis and Commentary}

Although the specific content of the burdens imposed by section 11 has been examined by courts and commentators in some detail, ${ }^{67}$ the precise issue of its relationship to the burdens of sec-

Id.

67 Section 11 had been little used, and directors, experts, and underwriters had fallen into the habit of discharging their statutory duties through perfunctory "due diligence meetings," until the force of the statute was rediscovered in Escott v. BarChris Constr. Corp., 283 F. Supp. 643 (S.D.N.Y. 1968). In that case, which was electrifying not because it was innovative but because it applied the statutory requirements literally, the defendants included the entire spectrum of parties governed by section 11: current and incoming direc- 
tion 12(2) has been discussed very little. Most of the commentary on the problem has concluded that the "reasonable investigation" requirement of section 11 is more stringent than the "reasonable care" requirement of section 12(2). For example, a contemporary analysis of the 1933 Act observed that "as to material untruths or omissions under Section 12(2) the standard applied is merely that of "reasonable care" "B8 and that "[t]he burden is placed on the dealer ... to prove "that he did not know, and in the exercise of reasonable care could not have known, of such untruth or omission.' The standard of reasonableness is not here defined as in Section 11(c) and presumably is somewhat less exacting." Some more recent analyses reach the same conclusion. The American Law Institute, for example, in formulating a model securities code, recognized the lack of clarity about the relative weight of the various duties of care imposed by the current law on various parties, but analyzed the law as containing three gradations in strictness: strict liability, which is illustrated by section 12(1); a standard of care that demands "reasonable investigation," which is illustrated by section 11's requirement that insiders be responsible for the non-"expertised" portions of their registration statements; and a' basic negligence standard, which is illustrated by the reliance on experts allowed under section 11 , and by section $12(2) .^{70}$

Two articles have disagreed. In the first, Professor Folk has argued that section 12(2) imposes a duty to investigate that is approximately equal to the insiders' duty to verify non-"expertised" portions of the registration statement. ${ }^{71}$ This position is directly contrary to the ALI understanding just described. Folk bases his

tors, underwriters, and auditors. The plaintiffs, purchasers of the debentures of a bowling alley construction company that went bankrupt and defaulted on its interest payments, brought suit alleging misrepresentations in the company's registration statement. The court discussed the relationships among the burdens expected of various parties, and among the various defendants' roles in the distribution process and their burdens of care. Id. at 682703. This case spawned abundant commentary. See, e.g., Folk, supra note 51.

is Douglas \& Bates, The Federal Securities Act of 1933, 43 YaLE L.J. 171, 208 (1933).

${ }^{89}$ Id. at 208 n.205.

7o ALI Federal Securities Code § 287(5) (Proposed Official Draft 1978); accord, John Nuveen \& Co. v. Sanders, 49 U.S.L.W. 3706, 3706 (U.S. Mar. 23, 1981) (Powell, J., dissenting from denial of certiorari) ("'Investigation' commands a greater undertaking than 'care' "). See also Lanza v. Drexel \& Co., 479 F.2d 1277, 1308-09 n.105 (2d Cir. 1973) (en banc); Committee on Federal Regulation of Securities, Current Issues and Developments in the Duties and Liabilities of Underwriters and Securities Dealers, 33 Bus. Law. 335, 39193 (1977); Comment, 44 N.Y.U. L. Rev. 226, 229 n.34 (1969).

${ }^{71}$ Folk, Civil Liabilities Under the Federal Securities Acts: The BarChris Case (pt. 2), 55 VA. L. REv. 199, 207-14 (1969). 
argument implicitly on the following syllogism: the "reasonable investigation" requirement in section 11 merely restates the common law;" the "reasonable care" requirement in section 12(2) also reflects common law standards; ${ }^{73}$ therefore the two phrases have essentially the same connotations. ${ }^{74}$ Furthermore, he argues that the same standard of reasonableness should be applied in both sections on the principle that a term used in adjacent portions of a statute should have the same meaning in both. ${ }^{75}$ These arguments are unconvincing for several reasons. First, even if both sections state common law duties, the duty to investigate may be required only in the particular range of the common law spectrum of care associated with the situations delineated by section 11, so that section $12(2)$ would not require investigation in every case. ${ }^{76}$ Second, the two sections apply to different kinds of people; the director and the broker may occupy different positions in the spectrum of common law duty. Finally, the principle of statutory construction that like terms ought to be defined alike within a statute is misplaced in this instance, because section 11 goes out of its way to define a special term, and the special meaning should not be generalized without specific guidance. Folk's general thesis that the 1933 Act's civil liability provisions speak with one voice and should be construed alike ${ }^{77}$ fails to explain why there are separate provisions at all and overlooks their very different origins as shown in the legislative history. The observation that sections 11 and 12(2) were enacted at the same time and for the same general purpose does not prove that their different language means the same thing: ${ }^{78}$ it

${ }^{72}$ But see note 51 supra.

${ }^{73}$ DeMarco v. Edens, 390 F.2d 836, 842 (2d Cir. 1968), holds that in the absence of a statutory definition the term "reasonable care" in section $12(2)$ should be construed by common law standards.

"Folk, supra note 71, at 211-12. Folk then qualifies this assertion somewhat: "Assuming arguendo that the reasonable care concept may sometimes entail an investigation, it would normally suffice for the [section 12(2)] defendant only to ask such questions and make such inquiries as are feasible under the circumstances." Id. at 213. If this is so, it is not helpful to equate the section 12(2) duties with those of section 11, even with the duties of one of the less responsible section 11 parties, because section 11 always requires investigation, whether by the insiders themselves or by the experts on whom they rely.

75 Id. at 212.

76 See text and notes at notes 64-66 supra.

77 Folk, supra note 71, at 212.

78 See id. at 211. But see John Nuveen \& Co. v. Sanders, 49 U.S.L.W. 3706, 3706 (U.S. Mar. 23, 1981) (Powell, J., dissenting from denial of certiorari): "In providing standards of care under the 1933 Act, Congress thus used different language for different situations. . . . The difference in language is significant, because in the securities acts Congress has used its words with precision." 
tends to prove the opposite.

In the second article, Professor Kaminsky goes beyond equating the two standards of care and suggests that section 12(2)'s demands may be even greater than section 11 's. ${ }^{79} \mathrm{He}$ focuses on the specific language of the affirmative defense in section 12(2): that the seller is liable unless he sustains "the burden of proof that he did not know, and in the exercise of reasonable care could not have known, of such untruth or omission." phrase "could have known," Kaminsky concludes that every seller is charged with constructive knowledge of every knowable fact, and that the seller therefore has none of the good-faith defenses expressly provided in section 11 to directors and others. ${ }^{81}$ This argument reads too much into the use of the word "could,"82 and reads out the reasonableness requirement altogether. The legislative history plainly demonstrates that section 11 defined primary responsibilities; $; 3$ thus any interpretation that would make mere sellers more responsible than directors is untenable. ${ }^{84}$

A separate objection to Folk's equation of "reasonable care" and "reasonable investigation," or to Kaminsky's argument that "reasonable care" is a more exacting standard, is that the consequences of putting those assumptions into practice would subvert the statutory scheme. As a first approximation it would make no difference how the burdens were distributed as long as they were clearly defined, because the affected parties would simply redistribute them by demanding higher compensation to cover the costs of compliance. If the increased costs are high enough, however, some transactions will become uneconomic and cease. Congress

79 Kaminsky, An Analysis of Securities Litigation Under Section 12(2) and How It Compares with Rule 10b-5, 13 Hous. L. REv. 231 (1976).

so 15 U.S.C. $\& 77 l(2)$ (1976).

B2 Kaminsky, supra note 79, at 275-77.

${ }^{82}$ The same expression is used in H.R. REP. No. 85, 73d Cong., 1st Sess. 9 (1933), to describe the duties of both section 11 and section 12(2), disproving that it has the meaning Kaminsky claims. As the ALI draftsmen noted in another context, "[i]t is perfectly obvious that many if not most of today's nuances are not only unnecessary but also harmful." ALI Federal Securities Code § 287(4) (Proposed Official Draft 1978).

ss See Part II-A supra.

84 For example, the broker who is paid a small commission could discover errors by independently verifying certified audit reports, on which the director is entitled to rely, but it would violate the scheme of gradations of responsibility to require him to do so. The statutory definition of underwriters, 1933 Act $\S 2(11), 15$ U.S.C. $\S 77 b(11)$ (1976), reflects this common-sense distinction: "such term shall not include a person whose interest is limited to a commission from an underwriter or dealer not in excess of the usual and customary distributors' or sellers' commission." 
made it clear that the burdens it meant to impose were not to be so high as to "impair honest business" or to operate as a prohibition rather than a regulation. ${ }^{85}$ To construe the distribution of statutory duties in a way that would ignore that limitation would undermine one of the statute's main purposes. ${ }^{86}$

But even if demanding a very high degree of care from section 12(2) parties as a matter of course would not shut down business, it certainly would offend good sense in another important way. Separate and independent verification of the registration statement or prospectus, especially by those with the least expertise or access to the facts, would be wasteful. Redundant investigations would do the investor a net disservice by increasing the cost of securities but adding no increment of protection. Congress recognized that such duplication may be undesirable when it allowed nonexperts to rely on expert data, rather than making both the experts and nonexperts liable under section 11 for misstatements in the "expertised" parts of the registration statement. Although section 11 does demand duplicative verification of the non-"expertised" parts by issuers, directors, and underwriters, ${ }^{87}$ the demand

${ }^{85}$ See text and notes at notes $43-45$ supra. See also John Nuveen \& Co. v. Sanders, 49 U.S.L.W. 3706, 3707 (U.S. Mar. 23, 1981) (Powell, J., dissenting from denial of certiorari) (if section 12(2) parties must perform section 11 investigations, "the efficiency of the shortterm financial markets will be impaired" (footnote omitted)).

so To the extent that the statutory scheme places high costs on a particular party rather than a whole category of transactions, it would theoretically be possible to reallocate costs voluntarily. Thus parties with overlapping duties might be expected to delegate the responsibility for compliance to the one for whom compliance is cheapest. The delegator would remain liable to purchasers in case of misrepresentation, but he could seek indemnity from the delegee who failed to comply. This model would produce maximum avoidance of harm at the lowest social cost. See Landes \& Posner, Joint and Multiple Tortfeasors, $9 \mathrm{~J}$. LEgAL Stud. 517, 526-28 (1980).

However, indemnification agreements-at least among parties subject to section 11-have been held to be against public policy: "Underwriters who knew they could be indemnified simply by showing that the issuer was 'more liable' than they (a process not too difficult when the issuer is inevitably closer to the facts) would have a tendency to be lax in their independent investigations." Globus v. Law Research Serv., Inc., 418 F.2d 1276, 1288 (2d Cir. 1969), cert. denied, 397 U.S. 913 (1970). See also Comment, supra note 70. The court in Globus may have been unsympathetic to the underwriter's indemnity claim in part because the underwriter knew about the misrepresentation, and therefore was not a cheaper cost avoider than the issuer. The court's assertion that independent investigation is a good thing in itself is probably true only in cases such as those in which revelation of the misrepresentation ruins the issuer and leaves the plaintiff with no solvent defendant save the independent verifier. If such collapses were common in the crisis preceding the enactment of the $1933 \mathrm{Act}$, one could argue that Congress intended indemnification to be unavailable.

87 See, e.g., Globus v. Law Research Serv., Inc., 418 F.2d 1276 (2d Cir. 1969), cert. denied, 397 U.S. 913 (1970). 
seems to have been motivated by a moral judgment that those who create the registration statement should be accountable for it, ${ }^{88}$ especially when they stand to profit by the sales it induces. ${ }^{89}$ This justification does not fit the seller, however, who need not fall into that category. If Congress meant the seller to have some duty to investigate, even a more modest one than that expected of more central figures in the issuance of the securities, one would expect it to have said so explicitly, especially in light of its explanation that the investigative burden may vary among parties covered by section 11 depending on their role in the distribution..$^{90}$ The separate provision for sellers suggests that their duty qua sellers is different in kind rather than degree..$^{91}$

\section{The Factors that Define the Standard of Care Under SECTION 12(2)}

The discussion so far has used the legislative history, the arguments of legal commentators, and some common-sense economics to support the proposition that the section 12(2) duty of care is neither identical to nor higher than section 11 duties. Section 12(2) cannot be explicated by a process of exclusion, however. The nature of the buyer-seller relationship and the particular features of the security sold help to give the 12(2) standard a distinctive yet flexible set of connotations and limits.

\section{A. The Buyer-Seller Relationship}

Under the 1934 Act, the SEC has a mandate to register associations of brokers and dealers ${ }^{22}$ whose rules

${ }^{8 s}$ For duties related to the distributional hierarchy, see H.R. REP. No. 85, $73 \mathrm{~d}$ Cong., 1st Sess. 9 (1933), quoted in note 65 supra.

s9 For the relevance of profit, see 1933 Senate Hearings, supra note 35, at 271 (statement of Ollie M. Butler): "[O]f one of two persons who must suffer for a mistake, it is more equitable that the one who had made the mistake should suffer than the innocent purchaser, particularly when the one who has made the mistake is making a profit in directing the company and selling the securities." Although the statement was made about the Senate proposal to hold directors strictly liable, the idea of correlating liabilities and rewards was not so limited, see note 38 supra.

${ }^{2}$ See note 65 supra.

91 Note that the seller cannot always avoid a duty to investigate, but such a duty is not imposed solely by section 12(2). For instance, an underwriter who markets a registered offering has duties to verify the registration statement under section 11 , to verify the prospectus as part of the registration statement under section 11, and not to make misleading representations in the prospectus under section 12(2).

${ }^{92} 1934$ Act § 15A, 15 U.S.C. § 780-3 (1976). 
are designed to prevent fraudulent and manipulative acts and practices, to promote just and equitable principles of trade, to foster cooperation and coordination with persons engaged in regulating, clearing, settling, processing information with respect to, and facilitating transactions in securities, to remove impediments to and perfect the mechanism of a free and open market and a national market system, and, in general, to protect investors and the public interest.93

One such organization, the National Association of Securities Dealers ("NASD"), has been registered, and has adopted Rules of Fair Practice. 94 One of the NASD rules has generated the "suitability" doctrine; out of the NASD rules, general notions of warranty, and its own administrative practice, the SEC has created the "shingle" theory. The question is whether either of these describes a buyerseller paradigm that should be incorporated, explicitly or implicitly, into the "reasonable care" requirement of section 12(2).

1. The Suitability Doctrine. Purchasers frequently have alleged violations of NASD or similar self-regulatory rules as the basis for damages in suits brought under the general jurisdiction section of the 1934 Act, ${ }^{85}$ usually in conjunction with claims impliedly arising under specific prohibitory provisions such as section 10(b)..$^{98}$ A particularly fertile source of such suits has been the NASD rule that requires members to have reason to believe that the securities they recommend are suitable for their customers' needs. ${ }^{97}$ Such suits have been entertained by the courts with varying degrees of receptivity, ${ }^{88}$ and they have engendered considerable

"3 Id. § 78o-3(b)(6).

- NASD Manual (CCH) กा 2001-2401 (1976).

os 1934 Act § 27, 15 U.S.C. § 78aa (1976).

's See, e.g., Shull v. Dain, Kalman \& Quail, Inc., 561 F.2d 152, 160 (8th Cir.), cert. denied, 434 U.S. 1086 (1977); Utah State Univ. of Agricultural \& Applied Science v. Bear, Stearns \& Co., 549 F.2d 164, 167-69 (10th Cir.), cert. denied, 423 U.S. 947 (1977); SEC v. First Sec. Co., 463 F.2d 981, 988 (7th Cir.), cert. denied, 409 U.S. 880 (1972); Buttrey v. Merrill Lynch, Pierce, Fenner \& Smith, Inc., 410 F.2d 135, 141-43 (7th Cir.), cert. denied, 396 U.S. 838 (1969); Colonial Realty Corp. v. Bache \& Co., 358 F.2d 178, 182 (2d Cir.), cert. denied, 385 U.S. 817 (1966).

97 NASD Rules of Fair Practice art. III, § 2, NASD Manual (CCH) I 2152 (1976). The New York Stock Exchange "know your customer" rule, NYSE RuLE 405, 2 NYSE Gume (CCH) If 2405 (1972), has invited similar attention.

2s The courts have dealt with two kinds of questions. One is under which of the rules, if any, actions may be implied. See, e.g., Buttrey v. Merrill Lynch, Pierce, Fenner \& Smith, Inc., 410 F.2d 135, 141-43 (7th Cir.) (actions implied under rules designed to protect public), cert. denied, 396 U.S. 838 (1969); Colonial Realty Corp. v. Bache \& Co., 358 F.2d 178, 182 (2d Cir.) (actions implied under rules whose place in the regulatory scheme justifies implica- 


\section{academic commentary.99}

The terms on which the suitability doctrine can avail purchaser plaintiffs have been changed, however. The rationale of Ernst \& Ernst $v$. Hochfelder's requirement of scienter in section 10(b) actions ${ }^{100}$ applies with greater force to actions not only implied but based on rules several removes from a statute, and would screen out many NASD-based $10 \mathrm{~b}-5$ complaints. ${ }^{101}$ More important, Touche-Ross \& Co. v. Redington ${ }^{102}$ counsels against the automatic implication of private rights of action simply because a statute is designed to protect securities purchasers. The force of these Supreme Court cases is to give new importance to section 12(2), which requires only negligence and specifically authorizes private suits. The new question, therefore, is whether the rules of self-regulatory organizations such as the NASD give specific and enforceable content to the statutory "reasonable care" requirement. ${ }^{103}$

The difficulty the courts have perceived in giving such effect to NASD rules is that some of them are designed to serve purposes other than defining duties to purchasers. ${ }^{104}$ This has led courts to

tion), cert. denied, 385 U.S. 817 (1966). The other question concerns what degree of fault makes violations actionable. Most cases have allowed the action only in cases of fraud. See, e.g., Shull v. Dain, Kalman \& Quail, Inc., 561 F.2d 152, 160 (8th Cir.), cert. denied, 434 U.S. 1086 (1977); Utah State Univ. of Agricultural \& Applied Science v. Bear, Stearns \& Co., 549 F.2d 164, 167-69 (10th Cir.), cert. denied, 423 U.S. 947 (1977). Buttrey, however, left open the question of whether negligence was sufficient.

${ }^{90}$ E.g., Lowenfels, Private Enforcement in the Over-the-Counter Securities Markets: Implied Liabilities Based on NASD Rules, 51 CoRNELL L.Q. 633 (1966); MacLean, Brokers' Liability for Violation of Exchange and NASD Rules, 47 DENyER L.J. 63 (1970); Rediker, Civil Liability of Broker-Dealers under SEC and NASD Suitability Rules, 22 ALA. L. REv. 15 (1969); Note, Implied Civil Liability Arising From Violation of the Rules of the National Association of Securities Dealers, 8 Loy. L.A.L. Rev. 151 (1975); Comment, Civil Liability for Violation of NASD Rules, 121 U. PA. L. REv. 388 (1972).

100425 U.S. at 206-11.

${ }^{102}$ Ernst \& Ernst therefore confirms the trend of allowing implication of actions under self-regulatory rules only in cases of fraud. See note 98 supra.

102442 U.S. 560 (1979). In Touche-Ross the Court refused to imply a private damages action from the filing requirements of section 17(a) of the 1934 Act, 15 U.S.C. $\$ 78 \mathrm{q}(\mathrm{a})$ (1976), the applicable SEC rules, and the rules of the New York Stock Exchange:

Certainly, the mere fact that $\S 17$ (a) was designed to provide protection for brokers' customers does not require the implication of a private damages action on their behalf. . . The ultimate question is one of congressional intent, not one of whether this Court thinks that it can improve upon the statutory scheme that Congress enacted into law.

442 U.S. at 578 (Rehnquist, J.).

${ }^{103}$ In Touche-Ross terms, the hypothetical question is whether the Court would have used the New York Stock Exchange rules to define a breach of the statutory filing requirements if it had found that section 17(a) created a private right of action for damages.

104 It was for this reason that the court in Colonial Realty Corp. v. Bache \& Co., 358 
engage in line drawing in order to segregate the rules under which implication is proper from those under which it is not. ${ }^{105}$

The more serious problem, however, is that treating even the selected rules as enforceable obligations under the statute accords them a force they should not have. ${ }^{108}$ It is more proper to treat the rules as no more than general indications of the duties the statute prescribes. This approach preserves the primacy of the statute and prevents the rules from being construed like statutes themselves. There are two dangers in construing self-regulatory rules like statutes: they may restrict the statute's general demand for reasonable care to their own specific compass, or they may liberate the statute from its prescribed bounds by importing terminology with a cloud of implications that Congress never intended. Moreover, there is a policy problem. Focusing on the rules that benefit purchasers, as the "suitability" doctrine seeks to do, might have the unfortunate effect of inhibiting the adoption of such rules. ${ }^{107}$ NASD and similar rules therefore should not provide an automatic roster of the demands of due care under section 12(2), although they may help provide a notion of what due care involves.

2. The Shingle Theory. Another source of general care prescriptions, similar to the suitability doctrine, is the "shingle" theory developed by the SEC in administrative proceedings. This the-

F.2d 178, 182 (2d Cir.), cert. denied, 385 U.S. 817 (1966), said that "the court must look to the nature of the particular rule and its place in the regulatory scheme, with the party urging the implication of a federal liability carrying a considerably heavier burden of persuasion than when the violation is of a statute or an SEC regulation."

10s See note 98 supra.

${ }^{106}$ The general problem is discussed in Fonda v. St. Paul City Ry., 71 Minn. 438, 449, 74 N.W. 166, 169 (1898):

Private rules of a master regulating the conduct of his servants in the management of his own business, although designed for the protection of others, stand on an entirely different footing from statutes and municipal ordinances designed for the protection of the public. The latter, as far as they go, fix the standard of duty towards those whom they were intended to protect, and a violation of them is negligence in law or per se. But a person cannot, by the adoption of private rules, fix the standard of his duty to others. That is fixed by law, either statutory or common. Such rules may require more, or they may require less, than the law requires; and whether a certain course of conduct is negligent, or the exercise of reasonable care, must be determined by the standard fixed by law, without regard to any private rules of the party.

107 See id. at 450,74 N.W. at 170:

A person may, out of abundant caution, adopt rules requiring of his employees a much higher degree of care than the law imposes. This is a practice that ought to be encouraged, and not discouraged. But, if the adoption of such a course is to be used against him as an admission, he would naturally find it to his interest not to adopt any rules at all. 
ory holds that when a broker-dealer hangs out his shingle, he impliedly makes certain representations to the public, such as that he is in compliance with the NASD rules, ${ }^{108}$ or that he has a reasonable basis for his representations, which in turn implies that he has conducted a reasonable investigation of the securities he sells and their issuer. ${ }^{109}$

The shingle theory originally was used only in disciplinary actions in which the SEC sought to revoke sellers' registrations under the 1934 Act or their membership in the NASD. The SEC established in those cases that when brokers and dealers fail to conduct reasonable investigations they have acted willfully and are therefore subject to revocation or other sanctions. ${ }^{110}$ Recently, however, the theory has been invoked by purchasers who allege implied misrepresentations as the basis of private damage suits. ${ }^{111}$ Importing the lore of administrative proceedings into the statutory scheme of damage actions is mistaken. "Reasonable investigation" may not mean the same thing in a disciplinary proceeding as it does in section $11 .{ }^{112}$ Still less should the shingle theory's construction of the term be used to gloss the "reasonable care" requirement of section 12(2). Furthermore, if every negligent violation of the NASD rules, no matter what the character of the rule, can be construed as an implied misrepresentation, and every misrepresentation transformed into a "willful" violation of the duty a seller owes his cus-

los See N. Wolfson, R. Phillips \& T. Russo, Regulation or Brokgrs, Dealers and SEcurities MARKETS 2-49 to -50 (1977).

${ }^{109}$ E.g., Richmond Corp., 41 S.E.C. 398, 406 (1963) ("By associating himself with a proposed offering, an underwriter impliedly represents that he has made such an investigation in accordance with professional standards"); Best Sec., Inc., 39 S.E.C. 931, 934 (1960):

Registrant's activity in the present case involved misrepresentations to customers in violation of the anti-fraud provisions of the Securities Acts. These provisions contemplate, at the least, that recommendations of a security made to proposed purchasers shall have a reasonable basis and that they shall be accompanied by disclosure of known or easily ascertainable facts bearing upon the justification for the representations.

See generally N. Wolfson, R. PhmLIPs \& T. Russo, supra note 108, at 2-13 to -17 .

110 E.g., Quinn \& Co. v. SEC, 452 F.2d 943 (10th Cir. 1971), cert. denied, 406 U.S. 957

(1972); R. A. Holman \& Co. v. SEC, 366 F.2d 446 (2d Cir. 1966), cert. denied, 389 U.S. 991 (1967); M.V. Gray Invs., Inc., 44 S.E.C. 567 (1971); Sanford H. Bickart, 43 S.E.C. 753 (1968); Leonard Lazaroff, 43 S.E.C. 43 (1966).

${ }_{111}$ See, e.g., Chasins v. Smith, Barney \& Co., 438 F.2d 1167, 1170-73 (2d Cir. 1970); Brennan v. Midwestern United Life Ins. Co., 286 F. Supp. 702, 707 (N.D. Ind. 1968), aff'd, 417 F.2d 147 (7th Cir.), cert. denied, 397 U.S. 989 (1970). See generally Hibbard, Private Suits Against Broker-Dealers: A Proposal to Limit the Availability of Rescissory Relief for Misrepresentations Implied by the Shingle Theory, 13 HARv. J. LEGIS. 1 (1975).

212 See text and note at note 139 infra. 
tomer not to misrepresent, the statutory scheme of graduated liability can be completely undone. All the objections to using the NASD rules as a checklist of sellers' duties to customers apply equally here, ${ }^{113}$ but the shingle theory, by creating a presumption of willfulness and an aura of fraud, goes even further.

Another objection to premising liability for damages on implied misrepresentations is that one may impliedly misrepresent by saying nothing at all. ${ }^{114}$ In the 1933 Act, however, Congress chose to impose liability for omission only when the omission causes statements that are made to become misleading, ${ }^{115}$ and in the Conference Report it made clear that the words mean what they say:

The Senate amendment imposed liability upon persons making false and deceptive statements in connection with the distribution or sale of a security. The House bill made the liability depend upon the making of untrue statements or omissions to state material facts. This phrase has been clarified in the substitute to make the omission relate to the statements made in order that these statements shall not be misleading, rather than making mere omission (unless the act expressly requires such a fact to be stated) a ground for liability where no circumstances exist to make the omission itself misleading. ${ }^{116}$

Like the suitability doctrine, the shingle theory does have one limited use in determining the content of a general duty of care owed by sellers to buyers. It emphasizes the professional seller's public aspect. If he holds himself out as a member in good standing of the NASD, he creates an expectation with the public that he complies with NASD rules. Beyond this point, however, the shingle theory adds nothing to the role conceded to the NASD rules under the suitability doctrine-namely, that they can be a rough indica-

11s The danger of construing the shingle theory rather than the statute presents itself here as well as in the suitability doctrine context, see text and notes at notes 106-107 supra. That it is easy to do is indicated by the reference to a "breach of the shingle theory" in $N$. Wolrson, R. Phillips \& T. Russo, supra note 108, at 2-50.

114 Two section 12(2) cases have involved implied misrepresentations. They do not dispose of the question of whether actions based on the shingle theory are proper, however, because in both cases the misrepresentations were implied from the defendants' actual statements that the securities were of good quality. Alton Box Bd. Co. v. Goldman, Sachs \& Co., 560 F.2d 916, 922-23 (8th Cir. 1977); Franklin Sav. Bank v. Levy, 551 F.2d 521, 527 (2d Cir. 1977).

11315 U.S.C. $\$ \S 77 \mathrm{k}(\mathrm{a}), 77 l(2)$ (1976).

136 H.R. Conp. Rep. No. 152, 73d Cong., 1st Sess. 26 (1933). 
tor of some of the duties inherent in the buyer-seller relationship.

\section{B. Variations in the Standard}

It may be that within an admittedly hazy general framework, specific elements of a particular relationship between buyers and sellers cause the duties to come more sharply into focus. Four of these elements can be identified with some certainty.

1. Bargaining for Less Care. The legislative history shows that Congress was motivated to enact the 1933 Act largely by concern for investor protection. But those protections are not costless, and the investor who does not need them may wish to bargain out of them to avoid superfluous expenditure. The structure of the Act indicates that private bargains with section $12(2)$ sellers about the level of care required may be more permissible than such bargains with section 11 parties, whose duties are defined more specifically. ${ }^{117}$ In fact, it seems proper to construe section 12(2)'s "reasonable care" in the light of private agreements, because the generality of the standard allows contemplation of all circumstances. This is an example of the superiority of the general reasonableness standard over the specific demands of the NASD rules.

One district court case, subsequently affirmed on appeal, has recognized that the seller and purchaser may bargain for less care. In Canizaro v. Kohlmeyer \& Co., ${ }^{118}$ the purchaser was an experienced investor in highly speculative securities who had recruited the defendant broker to handle a particular purchase the broker would not otherwise have handled. Although the broker failed to disclose certain information that might have affected the purchaser's decision to buy, the court held that the purchaser had come into the deal with open eyes and had received the care he had bargained for.

It would be unusual to see litigation involving such an agreement if it were specific and detailed. Parties who draft their way out of section 12(2)'s requirements probably cover enough contingencies to avoid lawsuits. Canizaro must be the more common case, in which a court is willing to infer a private agreement from the totality of the circumstances. Still sketchier would be the case in which only the sophistication of the buyer or the low level of compensation to the seller indicated a possibly deliberate altera-

117 See text and notes at notes 65-66, 85-91 supra.

118370 F. Supp. 282, 289 (E.D. La. 1974), aff'd, 512 F.2d 484 (5th Cir. 1975). 
tion of the buyer-seller relationship. Whether either alone would suffice is problematic.

2. Compensation. The responsibilities of various parties under the 1933 Act are proportional to their roles in the scheme of distribution. ${ }^{119}$ Compensation is one measure of the gradations in their roles. For instance, the underwriter, who has a more substantial relationship with the issuer than the broker does, ${ }^{120}$ is distinguished from the broker in terms of compensation by the statute itself. ${ }^{121}$ The SEC also recognizes that care and compensation are interdependent. ${ }^{122}$ Although no case explicitly turns on the issue of compensation, the issue should be one of the court's considerations in determining the reasonableness of a seller's care.

3. Sophistication. The sophistication of the purchaser is a factor that has been discussed and generally discarded by the courts. Defendants frequently urge that because the purpose of the 1933 Act was to protect, their burdens should be reduced when protection is unnecessary. Courts usually reply that sophisticated purchasers are just as entitled as unsophisticated ones to the protection of the laws, and that even a sophisticated buyer cannot make an informed judgment without complete disclosure. ${ }^{123}$ This response misses an important point, however: the sophistication that makes a difference in the level of care that is reasonable is not general worldliness, but specific knowledge (or perhaps ready access to it) concerning the specific security involved in the sale. As Canizaro demonstrates, such knowledge can be a proper consideration.

110 See text and notes at notes 65-66, 88-91 supra. See also note 84 supra.

${ }_{120}$ See University Hill Foundation v. Goldman, Sachs \& Co., 422 F. Supp. 879, 898-99 (S.D.N.Y. 1976).

${ }_{121} 1933$ Act $\S 2(11), 15$ U.S.C. $\$ 77 b(11)$ (1976), quoted in note 55 supra.

122 In recommending the adoption of a less rigorous registration procedure for certain kinds of securities, the SEC commented that

it is impractical to expect brokers whose compensation is limited to the minimum stock exchange commission to engage in a thorough and complete investigation of the issuer's affairs. A less rigorous "standard of reasonableness" for the purposes of Section 11 (c) of the Act could be prescribed by rule without sacrificing appropriate investor protections.

SEC, Summary of Disclosure Policy Study Report, [1963-1972 Transfer Binder] Fed. Sec. L. REp. Special StUdies (CCH) I 74,603. See also Committee on Federal Regulation of Securities, supra note 70, at 393.

${ }^{223}$ Hill York Corp. v. American Int'l Franchises, Inc., 448 F.2d 680, 690-91, 696 (5th Cir. 1971); Welch Foods, Inc. v. Goldman, Sachs \& Co., 398 F. Supp. 1393, 1398-99 (S.D.N.Y. 1974); Johns Hopkins Univ. v. Hutton, 297 F. Supp. 1165, 1217 (D. Md. 1968), rev'd on other grounds, 422 F.2d 1124 (4th Cir. 1970). 
4. Boiler Room Cases. The other side of the sophistication coin is that, if the purchaser is at a real informational disadvantage, the seller's duty may increase. One class of cases that illustrates this principle involves "boiler room" selling operations, in which the securities typically are unseasoned and speculative issues, sold by aggressive telephone solicitation. In disciplinary cases involving boiler rooms, the SEC has demanded a heavy burden of investigation even by the rather lowly salesmen, because the nature of the operation makes information supplied by the salesmen's employers inherently suspect. ${ }^{24}$ This increased duty has not been asserted in private suits, and probably should not simply be translated there in the formulation used in disciplinary proceedings, for the reasons outlined above. ${ }^{125}$ One's impression, however, is that the purchasers in such cases are precisely the gullible investors about whom Congress was concerned. In many cases the boiler room tactics may be egregious enough by themselves to constitute fraud and be actionable under rule 10b-5, but even in less extreme cases, the status of the purchaser might make those tactics unreasonably careless for section 12(2) sellers.

\section{The Nature of the Security Itself}

The boiler room cases have another facet: besides attracting unsophisticated buyers, they typically involve particularly risky investments. They suggest, therefore, that the nature of the security may also have a bearing on the definition of the standard of reasonable care under section $12(2)$.

1. Warning Signals. In the few cases that have been decided under section 12(2), most of the courts have based their decisions on the availability of correct information about the particular security and the likelihood that the seller would be alerted to look for it. As a rule, the cases have involved such obvious lapses ${ }^{126}$ or

124 Berko v. SEC, 316 F.2d 137 (2d Cir. 1963). There the court stated:

[T] he "public interest" requires that a salesman working out of a "boiler-room" be held to a higher duty to prospective customers than a salesman working out of a legitimate sales operation, and . . a "boiler-room" salesman does not meet his obligation when he has no knowledge other than opinions and brochures furnished by the broker, "without any checking, investigation, or determination of the correctness of the same before putting them out to the public."

Id. at 142 (quoting SEC v. Macon, 28 F. Supp. 127, 129 (D. Colo. 1939)). See also Hamilton Waters \& Co., 42 S.E.C. 784, 789 (1965).

${ }^{125}$ See text and notes at notes 108-113 supra.

${ }^{128}$ See, e.g., Alton Box Bd. Co. v. Goldman, Sachs \& Co., 560 F.2d 916 (8th Cir. 1977) (representation that notes of Penn Central were creditworthy despite knowledge of large 
such obvious diligence ${ }^{127}$ that the results are not difficult to reach. Another way of looking at the cases, though it is not a technique the courts have articulated, is to concentrate on the nature of the security involved. For example, in Murphy $v$. Cady 128 the security offered was stock in the South American Utilities Corporation, a "nice little operating company,"129 not listed on any exchange or in Moody's. No financial statement, report of earnings, or indeed any statement by the company accompanied the sale. The stock was supposed to have speculative possiblities because of the dearth of South American regulatory legislation and the favorable exchange rates, and an additional attraction was that the Chase Manhattan Bank was reported to have refused offers of $\$ 8.00$ a share and to be holding out for $\$ 12.00$. In fact the plaintiff, a small broker, bought at $\$ 4.50$, sold to his customers, repurchased when the price continued to fall, and ultimately recovered his losses from his seller under section 12(2). ${ }^{130}$

In Gould $v$. Tricon, ${ }^{131}$ the plaintiff bought almost 13,000 shares of a hitherto privately held company that was about to construct a plant to build and market a boat steering device. The company and several of its directors, though not subject to section 11's registration requirements, were held liable under section 12(2) for having made misrepresentations in the prospectus. They had said that the device was fully designed and that development was complete, but neglected to say that the device was likely to be the subject of litigation because its inventor had previously assigned all rights in it to another employer. The suggestion, not explicit in the case, is that stock in a new, untried venture may require more careful and complete scrutiny by the seller.

It seems clear, however, that stock in a company that has been

first quarter losses); Murphy v. Cady, 30 F. Supp. 466 (D. Me. 1939) (unchecked optimistic representations about speculative securities, when checking would have been simple), aff'd, 113 F.2d 988 (1st Cir.), cert. denied, 311 U.S. 705 (1940).

${ }^{127}$ See, e.g., DeMarco v. Edens, 390 F.2d 836 (2d Cir. 1968) (due care exercised when defendant had no reason to suspect that the underwriter would fail to deliver securities to purchasers); Gould v. Tricon, Inc., 272 F. Supp. 385 (S.D.N.Y. 1967) (defendant director not liable for failure to check accuracy of codirector's biographical statement).

${ }^{128} 30$ F. Supp. 466 (D. Me. 1939), aff'd, 113 F.2d 988 (1st Cir.), cert. denied, 311 U.S. 705 (1940).

129 Id. at 467.

130 The court dismissed the plaintiff's common law action for deceit, because he had not done any investigating, either. It treated section 12(2) as reversing the burden of proof: the seller would be liable under section 12(2) unless he could rebut the buyer's allegations. Id. at 468-69.

${ }^{131} 272$ F. Supp. 385 (S.D.N.Y. 1967). 
closely held but is now going public carries no per se warning signals. In DeMarco $v$. Edens, ${ }^{132}$ the company made an agreement with a reputable underwriter, complied with all the SEC filing requirements, and went public. The underwriter, in serious financial trouble, took the purchasers' money and never delivered their stock. The purchasers' 12(2) complaint against the solvent company was unsuccessful, ${ }^{138}$ because the underwriter apparently was reputable and nothing in the inquiries the company had made ought to have triggered its suspicions. Another way of formulating this consideration might be that the ordinary going-public sale of stock is not so risky as to require especially high standards of care concerning disclosure.

The SEC has insisted that brokers and dealers exercise increased care when the security is a "hot issue," an unseasoned and highly speculative venture. ${ }^{134}$ In a disciplinary proceeding context, the converse of this proposition also has been accepted: "[A]bsent actual knowledge or warning signals, a broker-dealer should not be under a duty to retain his own auditor to re-examine the books of every company, the stock of which he may offer for sale, even accepting the doubtful hypothesis that such permission would be granted."135

2. Registered Issues. A range of care proportional to the warnings sparked by the nature of the securities themselves is only a rough description of the demands of section $12(2)$, however. A refinement is suggested by the different roles the seller may play in the distribution scheme. In a registered offering, the underwriter/ seller naturally has a greater burden of care than the broker/seller: his section 11 duty to verify the registration statement overlaps with his section 12(2) duty to be careful about the prospectus, because the prospectus is a part of the registration statement. ${ }^{136}$ In

132390 F.2d 836 (2d Cir. 1968).

235 The purchasers did win a judgment against the underwriter, which was not appealed. $I d$. at 838 .

134 The Obligations of Underwriters, Brokers, and Dealers in Distributing and Trading Securities, Particularly of New High Risk Ventures, SEC Sec. Act Rel. No. 5275 (July 26, 1972), reprinted in SEC Proposed Hot Issues Controls, FED. SEc. L. REP. (CCH) Special Report No. 434 (July 26, 1972).

13s Levine v. SEC, 436 F.2d 88, 90 (2d Cir. 1971) (disciplinary suspension of broker's registration affirmed, because his intimacy with issuer put him on notice of misrepresentations).

136 See Form S-1, pt. 1, 1 Donnellay SEC HANDBook, supra note 18, at 3-2-3 to -32. See also In re Gap Stores Sec. Litigation, 79 F.R.D. 283, 307 (N.D. Cal. 1978); text and note at note 20 supra. The overlap is not quite complete, because the underwriter has a duty to 
this case, section 11 helps to define the duties of a particular kind of seller. Because section 11 rests on a legislative judgment about the underwriter's place in the scheme of distribution, that judgment may carry over to other representations, beyond those of the prospectus, that may be actionable under section 12(2) if not made with sufficient care. The high expectations on the underwriter with regard to the prospectus will color the degree of care it is reasonable for him to take in making other representations to purchasers. The broker, by contrast, does not occupy so high a place in the scheme of distribution, and should not be required to exercise the same degree of care. ${ }^{137}$

3. Unregistered Securities. Different problems arise when the security is unregistered. Then there can be no spillover effect from the duties imposed on a party by section 11 to the duties imposed on that same party solely under section $12(2)$, as in the case in which the underwriter's responsibility for the registration statement and the prospectus gives additional credit to any further representations he may make about the security. Nor can there be any reliance on an official prospectus by a seller subject only to section $12(2)$.

Section 12(1) covers securities that ought to have been registered but were not. ${ }^{138}$ A seller who deals in such securities is strictly liable. He has no defense based on his erroneous belief that the securities were not required to be registered. ${ }^{139}$ This provision both adds to the practical enforceability of section 5's registration requirement and ensures that the purchaser will have as wide as possible a choice of defendants. Between the section 11 defendants and the section 12(1) seller, there is almost certain to be a solvent

verify the accuracy of the registration statement as of the date it becomes effective, but is responsible under section 12(2) for the accuracy of the prospectus as of the date of sale. It would be unreasonable to hold the underwriter to section 11's standard, in effect to require a continuous process of investigation and verification of the official prospectus, during the gap between the time the registration takes effect and the time of the sale. A less stringent duty of care about changes in accuracy during the gap would be appropriate.

${ }^{137}$ Professor Loss assumes that reliance on the official prospectus by the seller who has no other role in the distribution is reasonable. 3 L. Loss, Securities Regulation 1708-09 (2d ed. 1961).

${ }_{138}$ See text and note at note 27 supra.

130 This standard of liability illustrates how different civil liability and administrative standards can be. In disciplinary proceedings the SEC suspends brokers' registrations when they take insufficient care about the validity of exemptions claimed by the issuer-a negligence rather than strict liability standard. See, e.g., Quinn v. SEC, 452 F.2d 943 (10th Cir. 1971); M.V. Gray Invs., Inc., 44 S.E.C. 567 (1971); Leonard Lazaroff, 43 S.E.C. 43 (1966); Isthmus S.S. \& Salvage Co., 42 S.E.C. 257 (1964). 
party.

Securities that are exempt from the registration requirements ${ }^{140}$ of section 5 are the harder case. Sellers are still liable for negligent misstatements under section $12(2)$ in that case, but their standard of care is particularly problematic because they have no official information on which to rely. The SEC has argued that in such cases the protection of investors demands that the seller exercise more than his usual care: "The mere fact that a security may allegedly be exempt from the registration requirements ... does not relieve a dealer of [his] obligations. On the contrary, it may increase his responsibilities, since neither he nor his customers receive the protection which registration under the Securities Act is designed to provide."141 This argument is seriously flawed. Exemption from registration was not intended to relieve issuers and directors of burdens at the broker's expense. Rather, Congress chose to exempt "certain types of securities and securities transactions where there is no practical need for the Act's application or where the public benefits are too remote."142 Making the seller fulfill the function that would have been served by registration defies the legislative judgment that registration itself is unnecessary. Moreover, the justifications for imposing heavy duties of verification on directors-that they have access to the information and stand to benefit most by the sales-do not apply to mere sellers. At most the seller should be required to exercise his usual reasonable care, and the judgment of Congress that the exempted securities and transactions are relatively safe indicates that less care than usual may be reasonable. ${ }^{143}$

A recent case in the Seventh Circuit, Sanders v. John Nuveen $\&$ Co. (Sanders IV), ${ }^{144}$ presents the issue of what degree of care is required of the seller who deals in exempt securities. ${ }^{145}$ The

140 See note 12 supra.

162 Distribution by Broker-Dealers of Unregistered Securities, SEC Sec. Act Rel. No. 4445 (Feb. 2, 1962), [1961-1964 Transfer Binder] Fed. Sec. L. ReP. (CCH) \ 76,820, at 81,068 .

112 H.R. REP. No. 85, 73d Cong., 1st Sess. 5 (1933).

${ }^{143}$ Even if increased care on the part of sellers would benefit investors, that would not necessarily be a good reason to expand the seller's liability under the Act. It is important to remember that the federal remedy does not supplant state common-law and statutory ones. It is a special remedy with its own limitations and should not be expanded simply because a general remedy would be more effective.

141619 F.2d 1222 (7th Cir. 1980), cert. denied, 49 U.S.L.W. 3706 (U.S. Mar. 23, 1981).

148 Whether the commercial paper Nuveen sold was in fact exempt was an issue in the case. Section 3(a)(3) of the 1933 Act, 15 U.S.C. $§ 77(c)(a)(3)(1976)$, exempts from registra- 
plaintiffs in this case purchased from Nuveen the short-term commercial paper of Winter \& Hirsch, a consumer finance company. Before marketing the notes Nuveen questioned the officers of Winter \& Hirsch, examined the audit reports prepared by an apparently reputable accounting firm, and questioned Winter \& Hirsch's bank lenders. Unknown to the banks, Nuveen, or the purchasers, Winter \& Hirsch and its supposedly independent auditor had collusively concealed the issuer's insolvency for more than ten years. When the fraud came to light, Winter \& Hirsch defaulted on the notes purchased by the plaintiff, and left Nuveen as the only solvent possible defendant. The court held Nuveen liable as an underwriter under section 12(2) for failing to conduct a "reasonable investigation" of the kind required of underwriters of registered offerings under section 11.146 This decision presents several

tion "[a]ny note, draft, bill of exchange, or banker's acceptance which arises out of a current transaction or the proceeds of which have been or are to be used for current transactions, and which has a maturity at the time of issuance of not exceeding nine months." SEC Sec. Act Rel. No. 4412, 26 Fed. Reg. 9158, 9159 (Sept. 20, 1961), reprinted in 17 C.F.R. $\S 231.4412$ (1980), provides in addition, however, that to be eligible for the exemption the notes must be of prime quality and eligible for rediscounting by Federal Reserve banks, and of a type not usually sold to the general public. Relying on these requirements, the plaintiffs in Sanders amended their complaint to add a claim under section 12(1), asserting that the defendants had sold them unregistered nonexempt securities. The Sanders IV court declined to decide this issue and assumed arguendo that the securities were exempt. $619 \mathrm{~F} .2 \mathrm{~d}$ at 1223-24 n.1.

Whether small-denomination notes purchased by noninstitutional investors should be exempt from registration has been the subject of some controversy. See Staff REPORT of the SEC, The Financial Collapse of the Penn Central Company (Subcomm. Print 1972); Hicks, Commercial Paper: An Exempted Security Under Section 3(a)(3) of the Securities Act of 1933, 24 U.C.L.A. L. Rev. 227 (1976); Comment, The Commercial Paper Market and the Securities Acts, 39 U. CHI. L. REv. 362 (1972).

${ }^{140}$ Sanders began as a 10b-5 case in 1970. It first reached the Seventh Circuit on an appeal from the district court's ruling that the Winter \& Hirsch commercial paper qualified as a security under the 1934 Act, and that ruling was affirmed. Sanders v. John Nuveen \& Co. (Sanders I), 463 F.2d 2075 (7th Cir. 1972). After denial of certiorari, 409 U.S. 1009 (1972), the case returned to the district court, and Nuveen was held liable under section 10(b) of the 1934 Act. This decision was affirmed in Sanders II, 524 F.2d 1064 (7th Cir. 1975). The Supreme Court vacated this decision and remanded the case, 425 U.S. 929 (1976), for reconsideration in light of its decision in Ernst \& Ernst v. Hochfelder, 425 U.S. 185 (1976). On reconsideration, the Seventh Circuit reversed, holding that scienter had not been shown, but remanded for rulings on the plaintiff's alternate section 12(2) claim. Sanders III, 554 F.2d 790 (7th Cir. 1977). The district court allowed the plaintiffs to amend their complaint to add a section 12(1) claim, and found Nuveen liable under both section 12(1) and section 12(2). No. 70 C 597 (N.D. Ill. Jan. 10, 1979). On appeal, the Seventh Circuit affirmed with respect to section 12(2), adopting the reasoning of Sanders II, but did not reach the section 12(1) claim. Sanders IV, 619 F.2d 1222, 1223 n.1, 1228 (7th Cir. 1980), cert. denied, 49 U.S.L.W. 3706 (U.S. Mar. 23, 1981). Justice Powell dissented from the denial of certiorari, in an opinion joined by Justice Rehnquist. 
problems.

First, had the securities been registered, Nuveen's section 11 duties as an underwriter arguably would have entitled purchasers to expect a high degree of care when Nuveen performed other functions covered only by section 12(2). Even in that case, however, the court's determination of what Nuveen should have done is probably wrong. Demanding that Nuveen go behind the certified audit reports and beyond its questioning of Winter \& Hirsch's bank lenders ${ }^{147}$ is even more rigorous than section 11 requires. Section 11 parties, if they are not experts, are entitled to rely on the statements of experts, ${ }^{148}$ especially when the expert information arouses no suspicion whatever. The court's assertion that reasonable care required Nuveen to examine Winter \& Hirsch's federal income tax returns, corporate minutes, or accounting work papers $^{149}$ is explicable only as the product of hindsight.

Nuveen had no section 11 duties, however, if the securities were not registrable. ${ }^{150}$ The court assumed that this distinction made no difference, ${ }^{151}$ treating the standard of care to which underwriters should be held as a function of their status as underwriters, rather than as a function of their role in the distribution of registered securities. Like the SEC's argument about unregistered securities, the court's argument about underwriters is flawed. The statute itself defines underwriters very broadly as anyone who sells securities on behalf of an issuer, directly or indirectly, and earns more than the usual dealer's or broker's commissson. ${ }^{162}$ The notion that an underwriter has a duty to investigate does not come from the definition, ${ }^{16 s}$ but from section 11 itself. There the underwriter

147619 F.2d at 1228 (adopting the reasoning of Sanders II, 524 F.2d at 1071).

148 Escott v. BarChris Constr. Corp., 283 F. Supp. 643, 683-97 (S.D.N.Y. 1968). See text and notes at notes 25, 39-54 supra. See also John Nuveen \& Co. v. Sanders, 49 U.S.L.W. 3706, 3707 (U.S. Mar. 23, 1981) (Powell, J., dissenting from denial of certiorari) ("the Court of Appeals . . . seems to have imposed the higher duty prescribed by $\$ 11$ to investigate, but denied [Nuveen] the right to rely on 'the authority of an expert' that also is provided by \$11" (footnote omitted)).

149 Sanders II, 524 F.2d at 1069, approved in Sanders IV, 619 F.2d at 1228.

150 See note 145 supra.

${ }^{151}$ Indeed, it intimated that the lack of registration increased Nuveen's duty. Sanders IV, 619 F.2d at 1228 n.13.

1521933 Act $\S 2(11), 15$ U.S.C. $\S 77 \mathrm{~b}(11)$ (1976), quoted in note 55 supra.

${ }_{153}$ See Pharo v. Smith, 621 F.2d 656, 671 (5th Cir. 1980). The duty to investigate could perhaps be implied out of the compensation term; as suggested in text and notes at notes 119-122 supra, compensation might be one factor at which courts should look directly. Nuveen's gross profit on the sales of Winter \& Hirsch's commercial paper was $0.19 \%$. Appellants' Reply Brief at 359 n.*, Sanders III, 554 F.2d 790 (7th Cir. 1977). 
has a specific duty to investigate because he stands in a particular position in the distributional hierarchy and because he often is intimately involved in, and able to act as a check on, the preparation of the registration statement, which includes the prospectus. When the security is not registered, the underwriter cannot perform that distinctive function. Thus, in the context of unregistered securities, drawing distinctions between the 12(2) underwriter and other 12(2) sellers does not make sense. The predicate for the distinction, that the underwriter is chargeable with special knowledge and responsibilities, does not exist.

In holding Nuveen liable for failing to discover the conspiracy between the issuer and its auditor, the court seems to have been motivated by a conviction that the injured purchasers should have a judgment against a solvent defendant. It is important to remember, however, that neither the 1933 Act in particular nor all the securities legislation in the aggregate was designed to provide investors with insurance. One of the risks they still take is the risk that those the laws make liable for fraud will be unable to compensate for the harm they cause. ${ }^{164}$

\section{ConcLusion}

The Securities Act of 1933 created an intricate scheme of responsibilities. Because of recent restrictions in the use of section 10(b) of the Securities Exchange Act of 1934, the explicit remedies of the 1933 Act contained in sections 11 and 12 are likely to be used much more frequently in the future, making resolution of their ambiguities important. Section 12(2) in particular presents difficult problems of interpretation. The legislative history of the 1933 Act strongly suggests that the specific and generally high duty of care required by section 11 ought not to be read into section 12(2). Apart from that caveat, section 12(2) can be given definition and a measure of predictability in its operation if courts will consider certain enumerated factors rather than vague policy aims. These include the nature of the buyer-seller relationship in

${ }^{154}$ See John Nuveen \& Co. v. Sanders, 49 U.S.L.W. 3706, 3707 n.4 (U.S. Mar. 23, 1981) (Powell, J., dissenting from denial of certiorari): "For the most part, certified public accountants faithfully have fulfilled the trust placed on them. But where breaches by accountants occur, it is the accountants themselves-not those who rely in good faith on their professional expertise-who are at fault and who should be held responsible." 
general, any indications that the buyer-seller relationship has been deliberately and consensually altered, and the nature of the security sold.

Catherine Masters Epstein 